\title{
Establishment the Synchronization System for Mass Clonal Propagation of Sugarcane (Saccharumofficinarum L) through Shoot tip Culture
}

\author{
Mazhar Ali Khaskheli ${ }^{1}$, Shahla Karim Baloch ${ }^{1}$, Muhram Ali ${ }^{1}$, Ghulam Shah \\ Nizamani ${ }^{2}$,Shafqat Yasmeen ${ }^{2}$ Allah Jurio Khaskheli ${ }^{1}$, Sajad Ali Khaskheli ${ }^{3}$, \\ Anees-ur-Rahman ${ }^{1}$, Rawal Ahmed Qambrani ${ }^{3}$, Amna Qazi ${ }^{1}$ \\ ${ }^{1}$ Department of Biotechnology, Sindh Agriculture University, Tandojam \\ ${ }^{2}$ Plant Tissue Culture Laboratory, Nuclear Institute of Agriculture (NIA) Tandojam \\ ${ }^{3}$ Departmen of Plant pathology, Sindh Agriculture University, Tandojam
}

\begin{abstract}
The aim of present investigation was to examine the efficiency of three different sugarcane (Saccharumofficinarum L.) verities viz. NIA 1026-P7, NIA-87 and SG NIA-2476.A total of 20 explants (apical meristems) shoot tip were inoculated on MS Basal media along with various concentrations of 2, 4-D, BAP, Kinetin and IAA. The results of different verities showed that initial growth, number of micro shoots and shoot length was obtained in variety NIA-1026-P7, on MS medium supplemented with low concentration of 2 , 4Dichlorophenoxyacetic acid (2, 4-D) along with highest concentration of Benzyl aminopurine (BAP) and Kinetin. The variety SG NIA 2476 expressed modestly and was not sufficient as compared with other varieties. The established plantlets were transferred on the MS half strength rooting medium along with various concentrations of IBA and IAA. The results of different varieties showed that maximum number of micro roots and roots length were established in variety NIA 87, on the half strength MS medium plus $1.50 \mathrm{mg} / \mathrm{l} \mathrm{IBA,} 3.0 \mathrm{mg} / \mathrm{l}$ IAA and $25 \mathrm{~g} / \mathrm{l}$ of sugar.
\end{abstract}

Keywords-Auxin, Cytokinin, In-vitro, Plant Growth hormones, Sugarcane.

\section{INTRODUCTION}

Sugarcane (Saccharumofficinarum, L.) is the agroindustrial cash crop of Pakistan belongs to the poaceae family and cultivated in tropical and subtropical area of the world. Due to high economic importance in Pakistan mostly contributed share of country; where accounts about $70 \%$ of worlds total sugar production $[1,2]$. The production of sugarcane described a very promising picture and reached to historical high of 73.6 million tons showing with increase of $12.4 \%$ over the production of
65.5 million tons during 2015-16 and comfortably exceeded target of 67.5 million tons by a considerable margin of $9.0 \%$ [3]. Pakistan occupies $5^{\text {th }}$ position in respect to area under sugarcane crop and almost $15^{\text {th }}$ position in cane production but ranks far below in sugar production [4]. Pakistan average yield of sugarcane is 48.9 tonnes per hector as compared with globally which is nearby 65.5 tonnes per hector, however Egypt and India are getting around 60 tonnes and 121 tonnes per hector individually [5]. Inefficient yield and lower sugar recovery cause high production cost that's why Pakistan the minimum aggressive in domestic and global sugar markets [6]. Generally conventional propagation of sugarcane multiplied vegetatively by stem cuttings which suffered from low propagation rates, expensive labour, time consuming and potential transmission of pathogens through seed cane from generation to generation [7]. It is still a problem due to unfavourable climatic conditions. Thus, lack of viable fuzz production makes it difficult to improve sugarcane through conventional breeding in Pakistan [8]. Therefore, now a day's most widely used techniques plant tissue culture like a Micro propagation and in vitro propagation is currently the only realistic means of achieving rapid, large-scale production of disease-free quality planting material as seed canes of newly developed varieties in order to speed up the breeding and commercialization process in sugarcane [9]. Plant tissue culture is currently a powerful tool that plays a major role in rapid multiplication of disease free planting material of newly improved varieties through in vitro technique on continuous year rounded basis [10]. Shoot tip culture is relatively simple in vitro method for rapid propagation of selected sugarcane materials and the clean or pathogen free plant materials [11]. As a result of 
the regeneration of plants through tissue culture technique could be a viable option for improving the quality and productivity of sugarcane. So far, a lot of reports have been published in the tissue culture of sugarcane from different countries [12, 13].

The aim of present investigation to determine the efficiency of three different sugarcane varieties were tested their performance under synchronization system for regeneration of shoots and roots.

\section{MATERIAL AND METHOD}

\subsection{Collection of explants/ Growth media preparation}

The present experiment was done at Plant tissue Culture Laboratory, Plant Breeding Genetics Division, Nuclear Institute of Agriculture (NIA) Tando Jam. Three sugarcane' varieties Viz. NIA-1026-P7, NIA-87 and SGNIA-2476 were tested in this experiment. Fresh, healthy and young apical meristems were collected from Experimental Farm, Nuclear Institute of Agriculture (NIA) Tando Jam.The Murashige and Skoog [14]medium containing with different concentration of 2, 4-D, BAP, IAA and Kinetin for shoot induction, for induction of rooting plantlets were transferred half strength MS basal media added various concentrations of IBA and IAA.

\subsection{Surface Sterilization}

The excised young and mature shoot tip removed leaf sheath on the surface of explants and cut into 1 to $1.5 \mathrm{~cm}$ long segments and washed in running tap water for five minutes, surface disinfected using $70 \%$ ethanol for 40 second and then immersed in $10 \%$ sodium hypochlorite solution of commercial laundry bleach $(5.25 \% \mathrm{NaOCl})$. The $\mathrm{pH}$ of medium was adjusted at 5.7-5.8 before autoclaving and media was autoclaved at $121{ }^{\circ} \mathrm{C}$ for 20 minutes.

\subsection{Tissue culturing}

After that plant samples were brought under the laminar airflow cabinet and washed thrice with sterilized distilled water. The soft segment of apical meristem then cut into small disc and placed on MS basal medium supplemented with different concentration of plant growth hormones.

\subsection{Culture maintenances}

After successfully explants were inoculated in the culture bottles then these culture bottles were transferred in the incubator for one week, after one week it is again transferred in the growth room forUniform culture conditions were maintained as 16 -hour photoperiod at $25 \pm 2{ }^{\circ} \mathrm{C}$ for growth temperature.

\subsection{Obtained data and phenotypic analysis}

The experiments were laid out in completely randomized design (CRD) with three replications. The phenotypic data were collected, days taken shoot initiation, number of micro shoots, shoot length $(\mathrm{cm})$, number of micro roots and root length $(\mathrm{cm})$.

\subsection{Statistical Analysis}

The experimental data were recorded and subjected to factorial design of analysis of variance (ANOVA) under linear models of statistics to observe statistical differences among different traits of wheat using computer program, Student Edition of Statistix (SWX), Version 8.1 (Copyright, Analytical Software-USA). Further least significant difference (LSD) test was also applied to test the level of significance among different combination means 15,16$]$.

\section{RESULTS AND DICUSSION}

\subsection{Hormonal Concentration Regulates the Micro- Shoot Initiation}

The results of different varieties showed that days taken to shoots initiation (40.91) was observed in variety NIA1026-P7 and later days taken to shoots initiation (50.83) was recorded in variety SG-NIA-2476 (Figure 1).The results of different varieties indicated that maximum number of micro shoots were recorded (40.75) in variety NIA-1026-P7 and minimum number of micro shoots were observed (28.41) in variety SG-NIA-2476 (Figure 2).The results of varieties indicated that highest shoots length were recorded $(6.22 \mathrm{~cm})$ in variety NIA-1026-P7 and lowest shoots length were recorded $(5.58 \mathrm{~cm})$ in variety SG-NIA-2476 (Figure 3).The results of different varieties indicated maximum number of roots were recorded (14.58, 11.17 and 10.16) in varieties NIA-1026-P7, NIA87 and SG-NIA-2476 separately (Figure 4).The results of different varieties showed that days taken to shoots initiation concurred with [17] publicised a protocol for stimulation and organogenesis shoots proliferation, found early days to shoots initiation for tip extension were observed 15 and 20 days with the concentration MS media containing $3 \%$ sugar combined with BAP and Kin, $1.50 \mathrm{mg} \mathrm{L}^{-1} \mathrm{GA}_{3} 3.0 \mathrm{mg} \mathrm{L}^{-1}$ resulted about $100 \%$ explants showing shooting. However the result number of shoots which corresponded with [18] developed the method for callus and regeneration was set up under in vitro culture developing immature shoot tip as explants, maximum shoot enlistment was observed in MS medium added with $2.50 \mathrm{mg} \mathrm{L} \mathrm{L}^{-1}$ 2, 4-D, $2.0 \mathrm{mg} \mathrm{L}^{-1} \mathrm{BAP}$ and $0.5 \mathrm{mg} \mathrm{L}^{-1}$ NAA.The results equally comparable with [19] publicised that variety B4906 gave the highest (16.88) shoots with $5.94 \mathrm{~cm}$ average shoot length in MS medium added with $1.5 \mathrm{mg} \mathrm{L} \mathrm{L}^{-1} \mathrm{BAP}$ and $0.4 \mathrm{mg} \mathrm{L}^{-1}$ NAA while, $\operatorname{Pr} 1013$ delivered highest 11.70 shoots explants ${ }^{-1}$ with $4.48 \mathrm{~cm}$ shoot length on MS media sustained by $2.0 \mathrm{mg} \mathrm{L}^{-1} \mathrm{BAP}$ and $0.5 \mathrm{mg} \mathrm{L}^{-1} \mathrm{NAA}$ [17]. 
3.2 Rooting of established shoots inhibited by the interaction of Auxin-Verities

The results of different varieties indicated that highest roots length were observed $(5.90 \mathrm{~cm})$ in variety NIA -87 and lowest roots length were recorded $(4.66 \mathrm{~cm})$ in variety SG-NIA-2476 (Figure 5). Among the combinations, IBA and NAA indicated best response with professed establishing MS1/2medium added with $2.50 \mathrm{mgl}^{-}$ ${ }^{1}$ NAA showed best response and the highest number of roots per micro shoots were 13.9 obtained within 810days with average root length $4.3 \mathrm{~cm}$ for the variety Co-91017. The stronger root growth development was impacted by IBA at the concentration of $1.0 \mathrm{mg} \mathrm{L}^{-1}$ with the maximum number of 41 roots plant ${ }^{-1}$ and poor quality rooting response was observed at $0.1-0.5 \mathrm{mg} \mathrm{L^{-1 }} \mathrm{IBA}$ combined with $0.5-2.0 \mathrm{mg} \mathrm{\textrm {L } ^ { - 1 }}$ BAP. The concurred with[19] observed the rooting response at concentration of $2.50 \mathrm{mg} \mathrm{L}^{-1} \mathrm{IBA}$ and it exhibits 16 numbers of roots at the length of $1.1 \mathrm{~cm}$, whereas $0.5 \mathrm{mg} \mathrm{L}^{-1} \mathrm{NAA}+2.50 \mathrm{mg}$ $\mathrm{L}^{-1}$ IBA indicated rooting response with 11.3 with a number of roots and $3.7 \mathrm{~cm}$ root length.

\section{CONCULSION}

It was concluded that days to micro shoots initiation, number of micro shoots, can be obtained on $\mathrm{MS}+2.0 \mathrm{mg}$ $\mathrm{L}^{-1} 2$, 4-D + $4.0 \mathrm{mg} \mathrm{L}^{-1} \mathrm{BAP}+20 \mathrm{~g} \mathrm{~L}^{-1}$ sugar in variety NIA-1026-P7 (Figure 6-7). while the shoots length (cm) can be achieved on $\mathrm{MS}+1.0 \mathrm{mg} \mathrm{L}^{-1} 2,4-\mathrm{D}+4.0 \mathrm{mg} \mathrm{L}^{-1}$ $\mathrm{IAA}+2.0 \mathrm{mg} \mathrm{L}^{-1} \mathrm{Kin}+20 \mathrm{~g} \mathrm{~L}^{-1}$ sugar in variety NIA1026-P7, however the number of micro roots and roots length $(\mathrm{cm})$ can be obtained on $\mathrm{MS} 1 / 2+3.0 \mathrm{mg} \mathrm{L}^{-1} \mathrm{IBA}+$ $1.50 \mathrm{mg} \mathrm{L}^{-1} \mathrm{IAA}+30 \mathrm{~g} \mathrm{~L}^{-1}$ sugar in variety NIA-87.

\section{REFERENCES}

[1] Naz, S. 2003. Micropropagation of promising varieties of sugarcane and their acclimatization response. Activities on Sugar Crops in Pakistan. In: Proc. Fourth Workshop Res. Dev., 1-9.

[2] Anonymous. 2005. Sugar and sugarcane statistics Annual report, PSMA, pp. 63-64.

[3] GOP. 2017-18. Economic Survey of Pakistan. Ministry of Food, Agriculture and Livestock, Government of Pakistan, Statistics Division (Economic Wing), Islamabad, p. 22.

[4] Bahadar, K., M. Jamal, M. Sadiq, M. Sulaman, H. Azim, and M.S. Balouch. 2002. Genetic variation and ecological suitability of new sugarcane genotypes under the agro-climatic conditions of Bannu (NWFP). Pak. Sugar J., 17: 15-7.

[5] Anonymous. 2009. Agriculture Statistics of Pakistan. MINFAL. Is lamabad. Pakistan. 27-28.
[6] Khan, I.A., 2005. Effect of NPK fertilizers on the growth of sugarcane clone AEC86-347 developed at NIA, Tando Jam. Pak. J. Bot., 37: 355-360.

[7] Lakshmanan, P.,R.J. Geijskes, L.F. Wang,A. Elliote C.P.L. Golf, N. Berding, G.R. Smith. 2006. Developmental and hormonal regulation of direct shoot organogenesis and somatic embryogenesis in sugarcane (Saccharum spp. interspecific hybrids) leaf culture. Plant Cell Rep., 25(10): 1007-1015.

[8] Raza, G., A. Kazim, M. Zahid, M. Shahid, M. Arshad, and A. Shaheen. 2010. The response of sugarcane (SaccharumofficinarumL.) genotypes to callus induction, regeneration and different concentrations of the selective agent (genetic in 418). Africa J. Biotech., 9(51): 8739-8747.

[9] Dalvi, S.G., V.C. Vasekar, Y. Amit, P.N. Tawar, G.B. Dixit,D. Theertha, and R.B. Deshmukh. 2012. Screening of promising sugarcane somaclones for agronomic traits, and smut resistance using PCR amplification of inter transcribed region (its) of sporisoriumscitaminae. Sugar Tech., 14(1): 68-75.

[10] Raman, L.M. 2004. An efficient protocol for in vitromicropropagation of sugarcane. Sugar Tech., 6 : 85-87.

[11] Singh, B., G.C. Yadav, and M. Lal. 2001. An efficient protocol for micropropagation of sugarcane using shoot tip explants. Sugar Tech 3: 113-116.

[12] Dibax, R., B.D.A. Giovana, J.B.F. Carlos, P.M. Marília, D.O. Yohana, D.O. André. 2012. Plant regeneration of sugarcane cv. RB931003 and RB98710 from somatic embryos and acclimatization. J. Biotech. Biodivers., 2(3): 32-37.

[13] Nawaz, M., U. Ihsan, I. Naeem, Z.I. Muhammad and A.J. Muhammad. 2013. Improving in vitro leaf disk regeneration system of sugarcane (Saccharumofficinarum L.) with concurrent shoot/root induction from somatic embryos Turk. J. Biol., 37: 726-732.

[14] Murashige, T. and Skoog, F. 1962. A revised medium for rapid growth and bioassay with tobacco tissue cultures. Physiol., Plant, 15: 473-487.

[15] Analytical Software, Statistix 8.1 user's manual, Tallahas see FL. 2005.

[16] Gomez, K.A., and A. A. Gomez. 1984. Statistical Procedure for Agricultural Research, (2 eds.), P: 680. Wiley, New York, USA.

[17] Dash, M., P.K. Mishra, and D. Mohapatra. 2011. Mass propagaton via shoot tip culture and detection of genetic variability of SaccharumofficinarumL clones using biological markers. Asian J. Biotech., 1-10.

[18] Behera, K.K., and S. Santilata. 2009. Rapid in vitro micro propagation of sugarcane 
(Saccharumofficinarum L. cv-Nayana) through callus culture. Nature and Sci., 7(4): 1-10.

[19] Belete, G., K. Bantte and M. Diro. 2017. In vitro shoot multiplication of two sugarcane (Saccharumofficinarum L.) genotypes using shoot apical meristem. Adv. Life Sci. Tech, 53:13-19.
[20] Alam, R., S.A. Mannan, Z. Karim, and M.N. Amin. 2003 Regeneration of sugarcane (Saccharumofficinarum L.) plantlet from callus. Pak. sugar J. 18: 15-19.

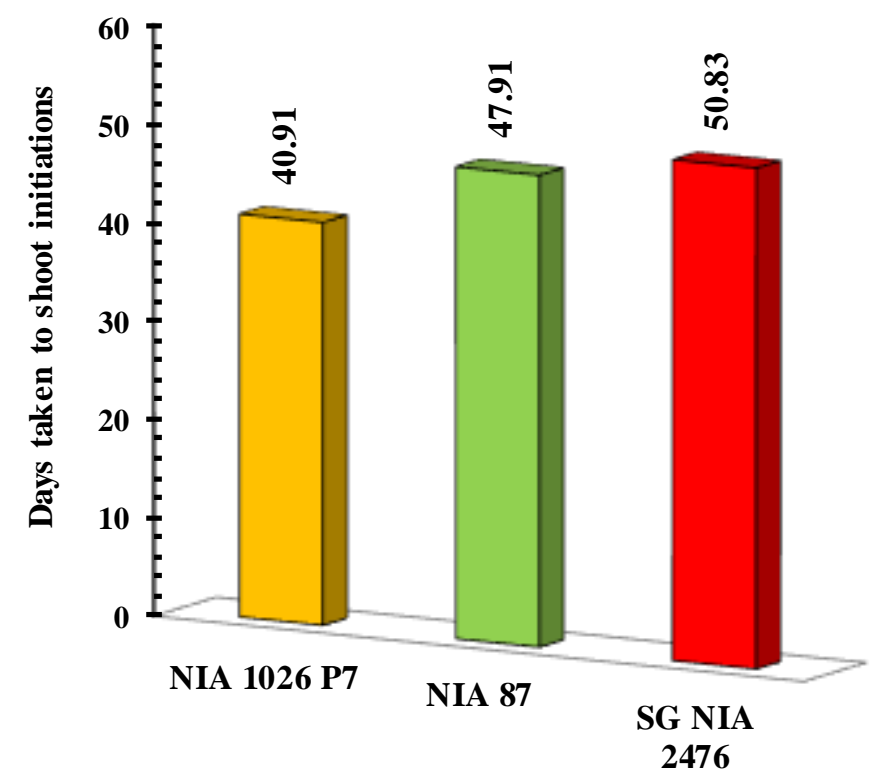

Fig.1: Invitro regeneration of sugarcane through shoot tip culture. The treatment means were compared using Least Significant Difference (LSD) at 5\% level of Probability. NIA 1026 P7, NIA87, SG NIA 2476 represents the different verities of sugarcane. Data are the average of three different biological replications.

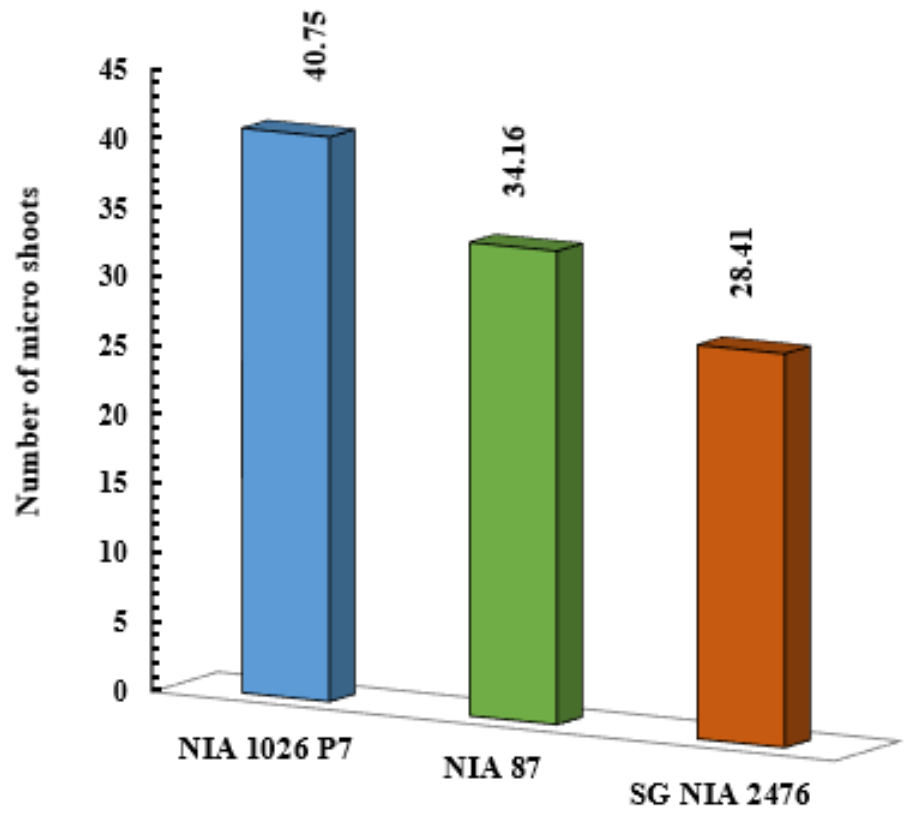

Fig.2: Encountering the number of micro shoots. The treatment means were compared using Least Significant Difference (LSD) at 5\% level of Probability. NIA 1026 P7, NIA87, SG NIA 2476 represents the different verities of sugarcane. Data are the average of three different biological replications. 


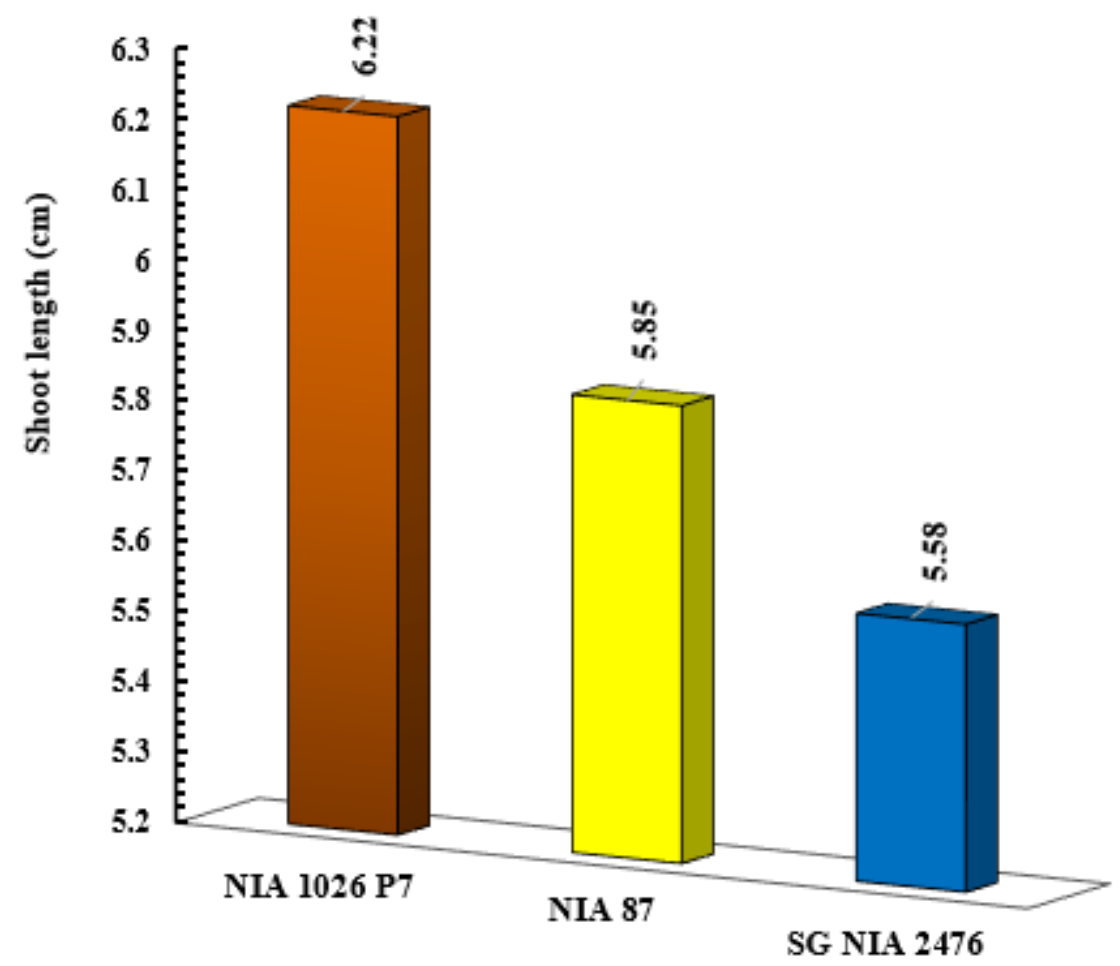

Fig.3: Shoots length modulated by different varieties of sugarcane. The treatment means were compared using Least Significant Difference (LSD) at 5\% level of Probability. NIA 1026 P7, NIA87, SG NIA 2476 represents the different verities of sugarcane. Data are the average of three different biological replications.

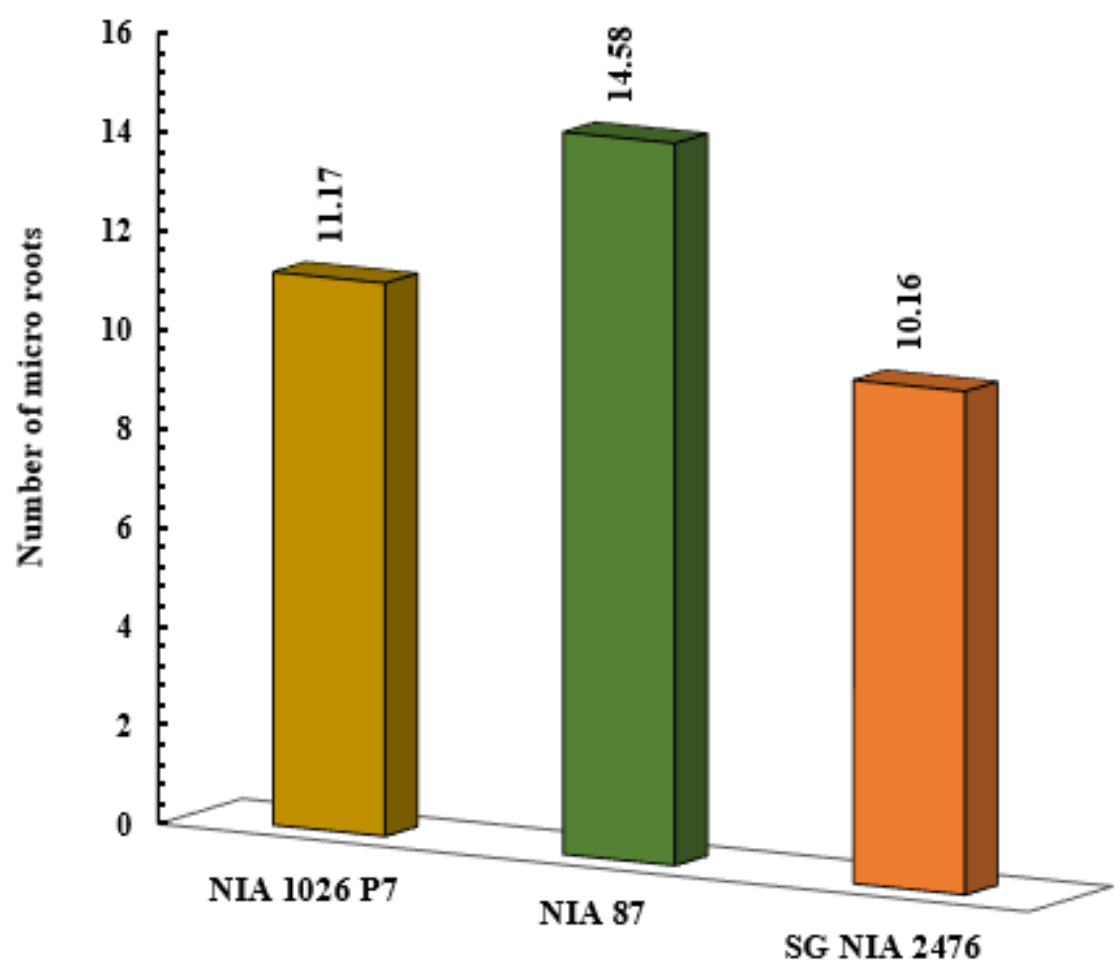

Fig.4: Micro roots maximization in different varieties of sugarcane. The treatment means were compared using Least Significant Difference (LSD) at 5\% level of Probability. NIA 1026 P7, NIA87, SG NIA 2476 represents the different verities of sugarcane. Data are the average of three different biological replications. 


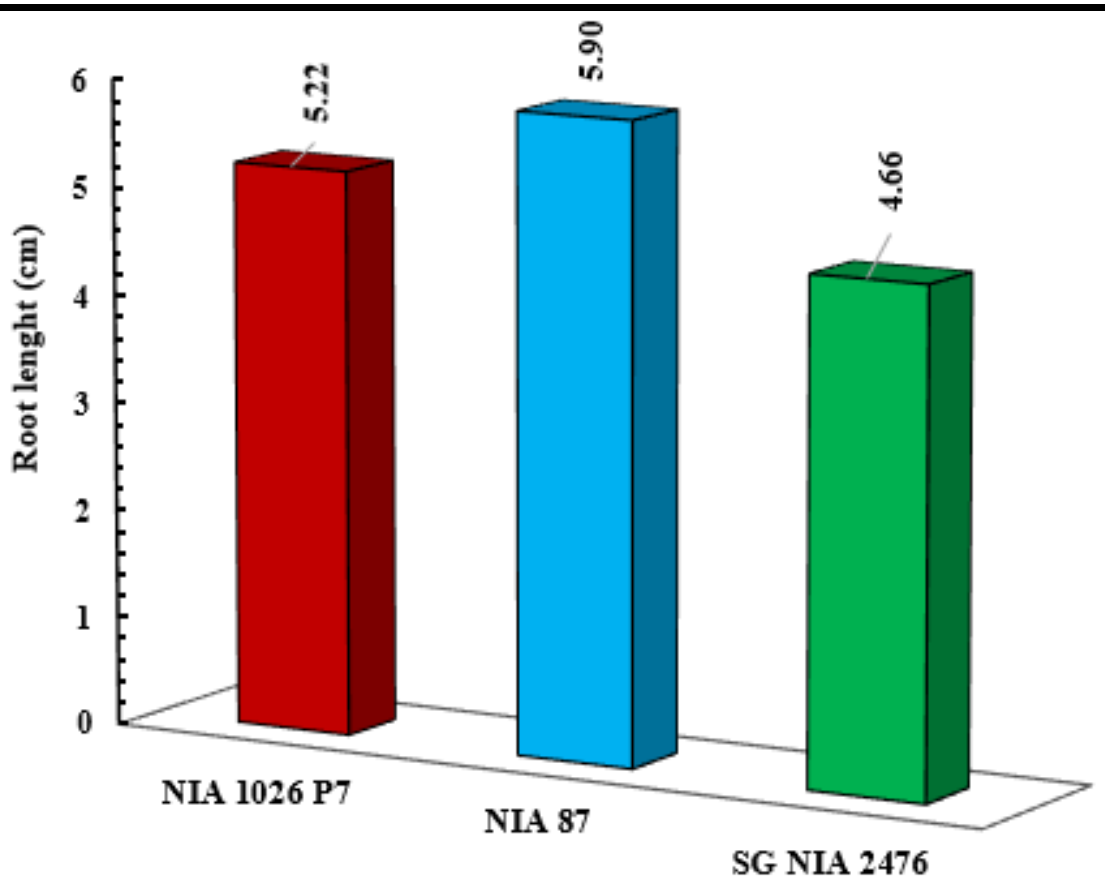

Fig.5: Slight inhibition of root length. The treatment means were compared using Least Significant Difference (LSD) at 5\% level of Probability. NIA 1026 P7, NIA87, SG NIA 2476 represents the different verities of sugarcane. Data are the average of three different biological replications.
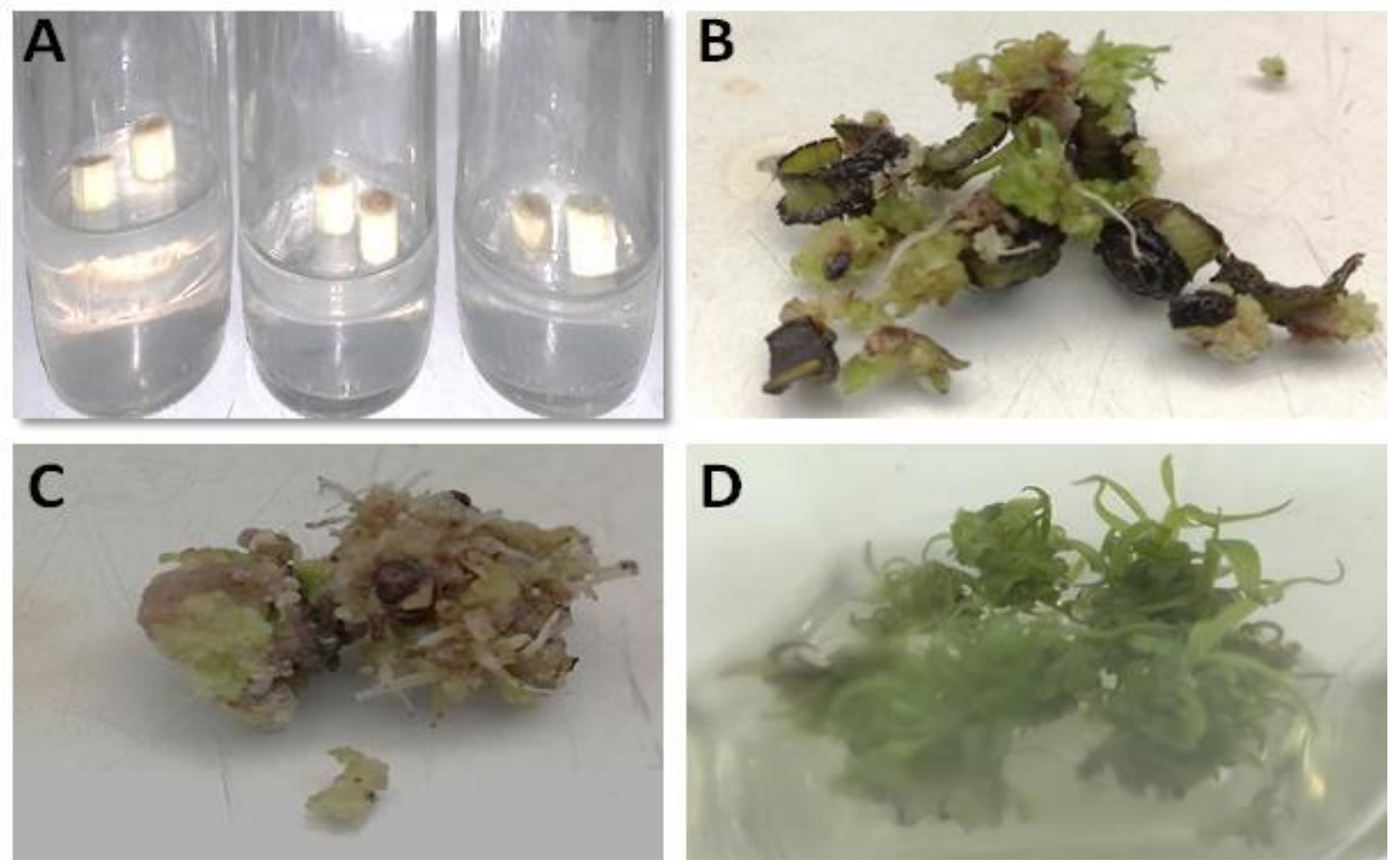

Fig.6: Mass-clonal proliferation of sugarcane on invitro condition. (A)Disc inoculated in the culture bottles(B)Growth starting from small segment of meristic tissue $(C)$ Differentiate the tissue in the micro shoots $(D)$ Establishment of seedling.

Experiments performed thrice as different biological replications. Data so obtained at two days interval on each replications. Regenerated shoots were then transferred to rooting media. 

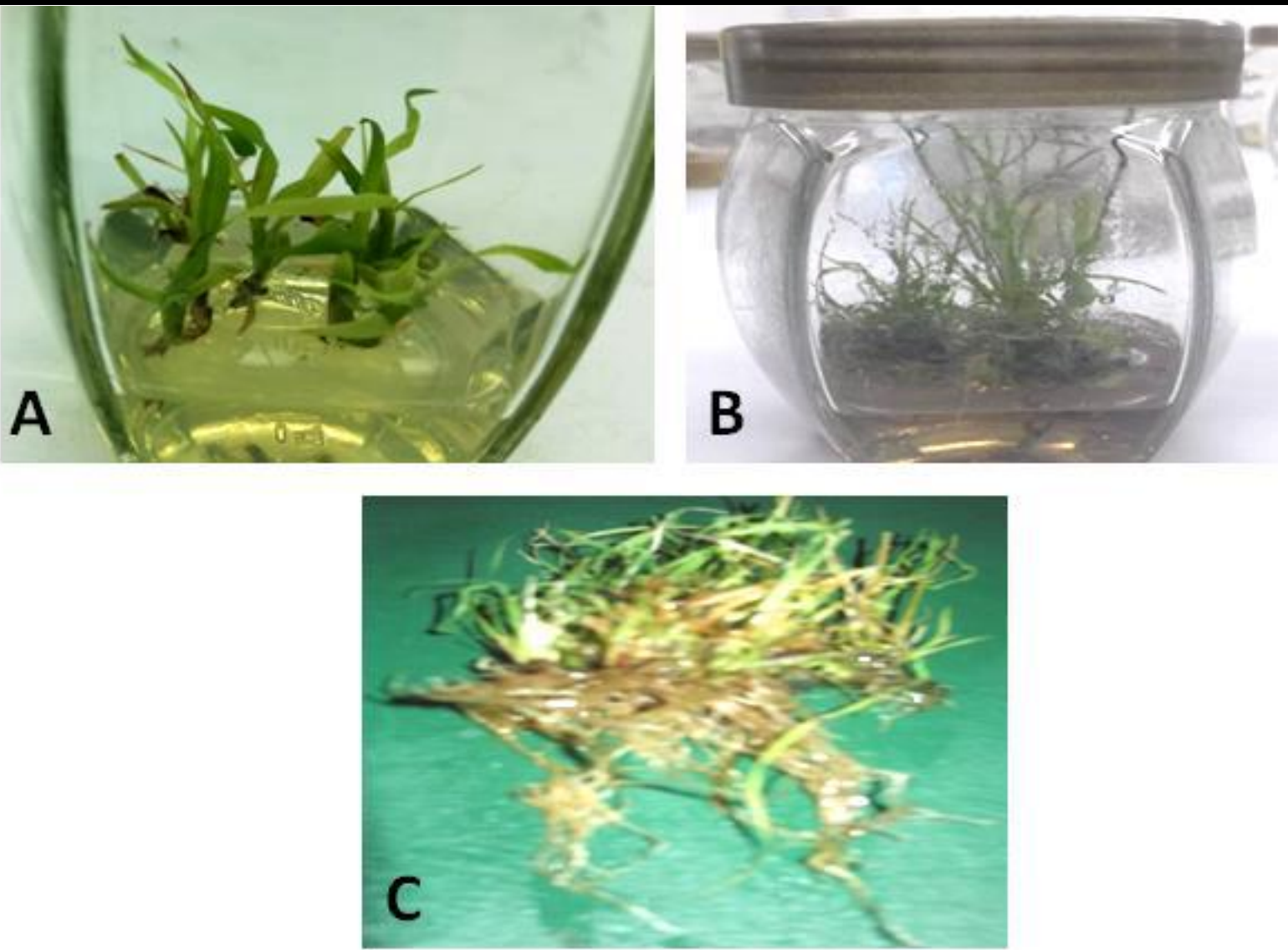

Fig.7: Mass-clonal production and multiplication of sugarcane. (A) Plantlets ready for establishing further height (B) Height of seedling $(C)$ Established maximum micro roots and its length Experiments performed thrice as different biological replications. Data so obtained at two days interval on each replications. Rooted seedlings ready for acclimatization

\section{Supplementary Tables}

Table S.1. Regeneration of sugarcane on controlled condition.

\begin{tabular}{|c|c|c|c|}
\hline & \multicolumn{3}{|c|}{ Days taken to shoot initiations } \\
\hline Varieties & NIA-1026-P7 & NIA-87 & SG-NIA-2476 \\
\hline Mean & $40.91 \mathrm{c}$ & $47.91 \mathrm{~b}$ & \multicolumn{2}{|c|}{ SG-NIA-2476 } \\
\hline & \multicolumn{3}{|c|}{ Number of micro shoots } \\
\hline Varieties & NIA-1026-P7 & NIA-87 & S \\
\hline Mean & $40.75 \mathrm{a}$ & $34.16 \mathrm{~b}$ & SG-NIA-2476 \\
\hline & & NIA-87 & $5.58 \mathrm{~b}$ \\
\hline Varieties & NIA-1026-P7 & $5.85 \mathrm{~b}$ & SG-NIA-2476 \\
\hline Mean & $6.22 \mathrm{a}$ & Number of micro roots & \multicolumn{2}{|c|}{ NIA-87 } \\
\hline & \multicolumn{3}{|c|}{$10.16 \mathrm{~b}$} \\
\hline Varieties & NIA-1026-P7 & Root length & SG-NIA-2476 \\
\hline Mean & $11.17 \mathrm{~b}$ & NIA-87 & $4.66 \mathrm{c}$ \\
\hline
\end{tabular}


Table S.2 Composition of MS basal medium (Murashige and Skoog, 1962)

\begin{tabular}{|c|c|c|c|}
\hline \multicolumn{4}{|c|}{ INGREDIENTS OF MS MEDIUM } \\
\hline \multirow[t]{2}{*}{ Serial No } & \multicolumn{3}{|c|}{ Macro Nutrients } \\
\hline & Ingredients & Chemical composition & Weight $\mathrm{mg} \mathrm{l}^{-1}$ \\
\hline 1 & Potassium nitrate & $\mathrm{KNO}_{3}$ & $23.5 \mathrm{~g} \mathrm{l}^{-1}$ \\
\hline 2 & Ammonium nitrate & $\mathrm{NH}_{4} \mathrm{NO}_{3}$ & $20.5 \mathrm{~g} \mathrm{l}^{-1}$ \\
\hline 3 & Calcium chloride & $\mathrm{CaCL}_{2} 2 \mathrm{H}_{2} \mathrm{O}$ & $5.5 \mathrm{~g} \mathrm{l}^{-1}$ \\
\hline 4 & Potassium diphosphate & $\mathrm{KH}_{2} \mathrm{PO}_{4}$ & $2.5 \mathrm{~g} \mathrm{l}^{-1}$ \\
\hline 5 & Magnesium sulphate & $\mathrm{MgSO}_{4} 7 \mathrm{H}_{2} \mathrm{O}$ & $4.5 \mathrm{~g} \mathrm{l}^{-1}$ \\
\hline \multirow[t]{2}{*}{6} & Potassium nitrate & $\mathrm{KNO}_{3}$ & $23.5 \mathrm{~g} \mathrm{l}^{-1}$ \\
\hline & \multicolumn{3}{|c|}{ Micro Nutrients } \\
\hline 7 & Boric Acid & $\mathrm{H}_{3} \mathrm{BO}_{3}$ & 0.31 \\
\hline 8 & Manganesesulphate & $\mathrm{MgSo}_{4} 4 \mathrm{H}_{2} \mathrm{O}$ & 1.15 \\
\hline 9 & Zinc sulphate & $\mathrm{ZnSo}_{4} 7 \mathrm{H}_{2} \mathrm{O}$ & 0.430 \\
\hline 10 & Ferrous sulphate & $\mathrm{Fe} \mathrm{SO}_{4} 7 \mathrm{H}_{2} \mathrm{O}$ & 1.390 \\
\hline 11 & Sodium molybdate & $\mathrm{Na}_{2} \mathrm{M}_{0} \mathrm{O}_{4} 2 \mathrm{H}_{2} \mathrm{O}$ & 0.12 \\
\hline 12 & Copper sulphate & $\mathrm{CuSO}_{4} 5 \mathrm{H}_{2} \mathrm{O}$ & 1.25 \\
\hline \multirow[t]{2}{*}{13} & Cobalt chloride & $\mathrm{CoSo}_{3} 6 \mathrm{H}_{2} \mathrm{O}$ & 1.25 \\
\hline & \multicolumn{3}{|c|}{ Iron source } \\
\hline 14 & Iron Sulphate & $\mathrm{FeSo}_{4} 7 \mathrm{H}_{2} \mathrm{O}$ & 27.8 \\
\hline \multirow[t]{2}{*}{15} & Sodium EDTA & $\mathrm{Na}_{2}$ EDTA & 1.865 \\
\hline & \multicolumn{3}{|c|}{ Vitamins } \\
\hline 16 & Thiamine HCL & $\mathrm{C}_{12} \mathrm{H}_{8} \mathrm{~N}_{8} \mathrm{OSCL}_{2}$ & $2.0 \mathrm{mg} \mathrm{l}^{-1}$ \\
\hline \multirow[t]{2}{*}{17} & Myo-inosital & & $200 \mathrm{mg} \mathrm{l}^{-1}$ \\
\hline & \multicolumn{3}{|c|}{ Other } \\
\hline 18 & Sugar & $\mathrm{C}_{12} \mathrm{H}_{22} \mathrm{O}_{11}$ & $20 \mathrm{~g} \mathrm{l}^{-1}$ \\
\hline 19 & Agar & & $7.5 \mathrm{~g} \mathrm{l}^{-1}$ \\
\hline 20 & $\mathrm{pH}$ & & 5.8 \\
\hline
\end{tabular}

